\title{
FEAR OF COMMITMENT: WEAK INSTITUTIONS, VOLATILE ECONOMY, AND THE PREVALENCE OF SHORT-TERM INTERNATIONAL CAPITAL
}

\author{
Nikola Tasić1 \\ Georgia State University, Atlanta, USA \\ Vladimir Ristanović ${ }^{2}$ \\ Institute of European Studies, Belgrade, Serbia
}

\begin{abstract}
This paper shows that weak legal and political institutions and high macroeconomic volatility shorten the maturity of cross-border bank lending. Although these results are confirmed in the previous literature, this paper uses a broader panel data set of 135 countries from 1983 to 2012. Data also suggest new finding that the maturity of international bank credit and per capita GDP are positively correlated. The share of debt incurred by banks shortens the maturity, while the share of debt incurred by governments lengthen the maturity of cross-border credit. Our results are robust after we control for potential endogeneity.
\end{abstract}

Key words: International lending, debt maturity, BIS reporting banks

\section{INTRODUCTION}

Diamond (1991, p.715; 2004, p.1453), Giannetti (2003, p.201), \& Rajan (1992, p.1383) argue that lenders use the maturity profile of credit to control borrower risk, especially in countries with weak institutions. Unsure of the strength of lender protection by the legal system, lenders prefer to finance firms with short-term credit and to decide whether or not to renew the loans after observing the performance of the borrower. The threat that credit may not be renewed is used to reduce the opportunistic behaviour of borrowers. Short-term credit also allows lenders to pull out faster if the legal, regulatory or political environment starts to deteriorate. In support of these ideas, Qian \& Strahan (2007, p.2824), Demirgüç-Kunt \& Maksimovic (1999, p.314), Tasic \& Valev (2010, p.164) provide empirical evidence that bank credit maturity is shorter in countries with weak institutions.

In this paper we address the same question but in the international context. In particular, we investigate whether the maturity of cross-border bank credit is shorter in countries with weak institutions. The literature has studied the determinants of credit maturity of domestic credit but provides only limited evidence on the determinants of the maturity of international credit.

\footnotetext{
${ }^{1}$ nikola@tasic.net

2 vmristanovic@gmail.com
} 
Understanding the factors that influence the international credit maturity is important. Radelet \& Sachs (1998), Chang \& Velasco (2001) attribute the onset of international financial crises in late 1990s to a buildup of large volumes of short-term debt. Deteriorating economic fundamentals, a shift in market expectations or risk preferences, or contagion may trigger a sudden capital outflow with devastating consequences for currency values, the domestic financial system, and the wider economy. That problem is exacerbated if a large part of international debt is short-term and can be pulled out rapidly. Indeed, the literature shows that large volumes of short-term debt are an important predictor of crises. There is, however, limited evidence on why a large fraction of international credit is short-term. Here we provide such evidence. We use a large data set on international bank lending to 135 countries from 1983 to 2012 to investigate the determinants of the maturity of international credit, with the particular emphasis on the role of legal and political institutions. We find that weak rule of law and political uncertainty significantly reduce the fraction of international credit that is long-term. Furthermore, we find that the effect of weak rule of law is particularly pronounced in more developed countries. Besides institutions, economic volatility measured as erratic changes foreign exchange reserves, exchange rates, and inflation also shortens the maturity of credit.

We extend the literature that has studied the maturity of domestic credit (Qian \& Strahan, 2007, Demirgüç-Kunt \& Maksimovic, 1999, Tasic \& Valev, 2010) by investigating international credit. We also extend the literature that has studied the effect of institutional and political uncertainty on the level and cost of international capital (De Haan et al. 1997) by investigating the credit maturity instead. Our paper is not the first analysis of the determinants of international credit maturity. Rodrik \& Velasco (1999) investigate international credit maturity for a sample of developing countries, Buch \& Lusinyan (2003) investigate maturity in a cross-sectional setting, and Valev (2006 and 2007) investigates the determinants of international lending by U.S. banks. We build on the analysis of these papers with 1) a more comprehensive set of institutional and political variables; 2) a substantially larger set of countries under investigation; 3) incorporating instrumental variable techniques and 4) broadening the data to include lending by all Bank of International Settlements (BIS) reporting banks.

In the following section we present empirical hypotheses and data. Section 3 presents the results and Section 4 concludes. 
Fear of commitment: weak institutions, volatile economy, and the prevalence of..

\section{EMPIRICAL HYPOTHESES AND DATA}

The next section reports estimates of the following equation (eq. 1):

Maturity $_{i t}=$

$\alpha+\beta_{1}$ Institutions $_{i t}+\beta_{2}$ Economy $_{i t}+\beta_{3}$ Imports $_{i t}+\beta_{4}$ P.C.GDP ${ }_{i t}+\beta_{5}$ FinancialDevelop

ment $_{i t}+\beta_{6}$ Government $_{i t}+\beta_{7}$ Banks $_{i t}+\beta_{8}$ Total Claims $_{i t}+\eta_{i}+\varepsilon_{i t}$

Maturity presents the two dependent variables: the percent of debt that has maturity one year or less (short-term debt) and the percent of debt that has maturity two years or more (long-term debt). Institutions are measured using Law and order and Investment profile indexes, while the Economy is measured using the Exchange rate volatility, Reserves volatility, and Inflation.

We begin the empirical investigation with a fixed-effects panel data estimator. However, Maturity, Government, Banks, and Total claims are jointly determined by construction and we need to control for endogeneity. Therefore, we later introduce the Hausman-Taylor (1981) estimator to correct for the correlation between the country-level random-effects $\left(\eta_{i}\right)$ and endogenous explanatory variables (Government, Banks, and Total claims). We use legal origin as instruments, and the model also allows us to estimate the impact of these time-invariant variables on maturity. This is not possible in the fixed-effects estimator. ${ }^{3}$

The following subsection presents data on Maturity. The next two subsections provide explanations of measures of Institutions and Economy, and the final subsection presents the rest of control variables (Imports, P.C. GDP, Financial Development, Government, and Banks).

\subsection{International Lending Data}

International lending data used in the paper are consolidated international claims by BIS reporting banks vis-à-vis the entire economy of the 135 countries $^{4}$, in billions of US dollars, for the period from 1983 to

\footnotetext{
${ }^{3}$ One additional concern is that dependent variables are a ratio (between 0 and 1 ), making OLS problematic as the predicted values might lay outside the unit interval (Papke and Wooldridge, 1996). This may require the transformation of the dependent variable using a $\log$-odds ratio $(\log ($ Maturity/1-Maturity)). However, the coefficient estimates using the log-odds ratio are difficult to interpret in a panel setting. Therefore, we follow the previous literature on determinants of maturity and do not perform the transformation. Also, below of predicted values in dataset in basic model layout of 0 to 1 interval.

${ }^{4}$ Albania, Algeria, Angola, Argentina, Armenia, Australia, Austria, Azerbaijan, Bahamas, Bahrain, Bangladesh, Belarus, Belgium, Bolivia, Botswana, Brazil, Brunei Durs. Bulgaria, Burkina Faso, Cameroon, Canada, Chile, China, Colombia, Congo, D. R., Congo, R.,
} 
2012. The data are published by the BIS in the Consolidated Banking Statistics. The data are broken down in terms of maturity into three categories: claims with the remaining maturity of one year or less (shortterm debt), claims with the remaining maturity longer than one year up to (and including) two years, and claims with the remaining maturity longer than two years (long-term debt). We use the percent of short-term debt and the percent of long-term debt. On average, 50.6 percent of the international lending activity by BIS-reporting banks was in short-term assets, while 43 percent was in long-term assets. Table 1 shows systematic differences related to economic development and legal origin. While the average Total Claims increases with income, upper middle income group's debt has the longest maturity (high income group has the shortest maturity). OECD member countries tend to have more foreign debt and the maturity of their debt is slightly longer. Countries with German legal origin have largest amounts of debt, but their debt has shortest maturity. Socialist countries have lowest amounts of debt and their debt has longest maturity compared to countries with other legal origin. The following two sections investigate what institutional and economic characteristics contribute to this distribution.

\subsection{Institutional Uncertainty}

Citron \& Nickelsburg (1987) and Ozler \& Tabellini (1991) show that in countries with high political uncertainty, current governments discount the future gains from access to capital markets and are more likely to default on their loans. Hence, political uncertainty is associated with lower loan volumes and with greater cost of borrowed funds (De Haan et al. 1997). In Rodrik \& Velasco (1999), upcoming elections result in either a "populist" or an "orthodox" government. As orthodox governments are

Costa Rica, Cote d'Ivoire, Croatia, Cyprus, Czech R., Denmark, Dominican R., Ecuador, Egypt, A. R., El Salvador, Estonia, Ethiopia, Finland, France, Gabon, Gambia, Germany, Ghana, Greece, Guatemala, Guinea, Guinea-Bissau, Guyana, Haiti, Honduras, Hong Kong, Hungary, Iceland, India, Indonesia, Iran, I. R., Ireland, Israel, Italy, Jamaica, Japan, Jordan, Kazakhstan, Kenya, Korea, R., Kuwait, Latvia, Lebanon, Liberia, Libya, Lithuania, Luxembourg, Madagascar, Malawi, Malaysia, Mali, Malta, Mexico, Moldova, Mongolia, Morocco, Mozambique, Myanmar, Namibia, Netherlands, New Zealand, Nicaragua, Niger, Nigeria, Norway, Oman, Pakistan, Panama, Papua New Guinea, Paraguay, Peru, Philippines, Poland, Portugal, Qatar, Romania, Russian Federation, Saudi Arabia, Senegal, Serbia, Sierra Leone, Singapore, Slovak R., Slovenia, South Africa, Spain, Sri Lanka, Sudan, Suriname, Sweden, Switzerland, Syrian A R., Tanzania, Thailand, Togo, Trinidad and Tobago, Tunisia, Turkey, Uganda, Ukraine, United Arab Emirates, United Kingdom, United States, Uruguay, Venezuela, Vietnam, Yemen, R., Zambia, Zimbabwe. 
Fear of commitment: weak institutions, volatile economy, and the prevalence of..

more likely to service international debt compared to populist governments, lenders prefer to lend short-term leading up to the elections. ${ }^{5}$ Therefore, greater institutional uncertainty shortens the maturity of international debt.

To measure institutional uncertainty, we use Law and order and Investment profile indexes from International Country Risk Guide (IRCG) database. The data are published by Political Risk Services (PRS) Group and they cover the period from 1984 to 2012. The PRS is a commercial service that provides financial, economic, and political risk assessment for international investors. The Law and order is comprised of two subcomponents: "the Law sub-component is an assessment of the strength and impartiality of the legal system, while the Order sub-component is an assessment of popular observance of the law" (ICRG). As both subcomponents range from 0 to 3, Law and order ranges from 0 to 6 by the definition. In our sample Law and order also ranges from 0 to 6, with an average of 3.679. The lowest value of Law and order was in Congo, Dem. Rep. (from 1991 to 1992), in Ethiopia (from 1991 to 1992), Serbia (from 1991 to 1992), in Somalia (from 1992 to 1993), and in Sri Lanka (from 1988 through 1991). The highest values of Law and order were observed in most OECD countries toward the end of the sample, but in countries like Brunei Darussalam, Kuwait, Morocco, Qatar, and Singapore as well.

The Investment profile "is an assessment of factors affecting the risk to investment that are not covered by other political, economic and financial risk components". The risk rating assigned is the sum of three subcomponents (each with a range from 0 to 4 ) and it ranges from 0 to 12 , with higher values indicating lower perceived risk. In our sample Investment profile also ranges from 0 to 12, with an average of 7.306. The lowest value of Investment profile was in Liberia (from 1991 to 1993), Myanmar (from 1989 and 1991), Serbia (in 1999), and in Sierra Leone (from 1998 to 1999). The highest values of Investment profile were again observed in most OECD countries toward the end of the sample.

\footnotetext{
${ }^{5}$ For example, concerns over election results in Brazil provide an excellent example for that framework. The New York Times (October 2, 2002, p.10) reports that "Much of the market nervousness can be attributed to growing worries about the presidential election to be held in October, a race now led by Luiz Inacio da Silva of the left-wing Workers' Party...Analysts here and on Wall Street fear that if Mr. da Silva is elected, he will renegotiate or even default on Brazil's foreign debt, a stance that his party has endorsed for most of its 20-year history." As a result, while Brazil was still able to refinance its international bonds, the maturity of "a chunk of them" is now "running for only one month." (The Economist, October 19, 2002, p. 68).
}

Vol. 23, број 1/2021, стр. 17-34 


\subsection{Economic Uncertainty}

Catao \& Sutton (2002) show that countries with greater macroeconomic volatility are more likely to default on international loans. In these countries lenders prefer short-term exposure so they can pull out if a crisis seems imminent. High volatility can be associated with short-term debt from the supply side. Conversely, from the demand side, high volatility might lead to longer maturity - countries with greater volatility prefer long-term debt in order to lock in terms of financing and to spread debt service payments over time. Therefore, the impact of macroeconomic volatility on the maturity of international debt remains an empirical question.

The economic uncertainty is measured by three volatility indicators: (1) the standard deviation of foreign exchange reserves over the last ten years (Reserves volatility), (2) foreign exchange rate depreciation against US dollar over the last five years (Exchange rate volatility), and (3) the cumulative CPI inflation over the last five years (Inflation). ${ }^{6}$ Aizenman \& Marion (2002) show that reserve volatility lowers foreign investment. Large devaluations are often associated with output decline, international defaults, and foreign debt restructuring. Price inflation was included to proxy for sound macroeconomic policies. On average, the standard deviation of foreign reserves was 5.97. The average change in the exchange rate over five years was 0.78 , while the average five-year inflation was around 183 percent.

\subsection{Remaining Control Variables}

Imports are measured relative to GDP, and this variable accounts for the trade related credit that tends to be short-term, i.e. more imports are expected to lead to more short-term credit. ${ }^{7}$ Cross-sectional research (e.g., Buch \& Lusinyan 2003) does not obtain a statistically significant effect of imports, while the research that considers lending from one country (e.g., Valev 2007) finds that imports shorten the maturity. ${ }^{8}$

\footnotetext{
${ }^{6}$ Economic uncertainty measures were constructed using data from the International Financial Statistics published by IMF and World Development Indicators published by the World Bank.

${ }^{7}$ Data on imports and GDP were obtained from the International Financial Statistics published by the IMF and World Development Indicators published by the World Bank.

${ }^{8}$ The aggregation in cross sectional research could drive this result of insignificant impact of imports - while Valev uses imports from the US and loans issued by US banks, cross sectional research considers overall volume of imports and lending from all banks.
} 
Fear of commitment: weak institutions, volatile economy, and the prevalence of..

P.C. GDP is per capita GDP in U.S. dollars and proxies for the level of economic development. Buch \& Lusinyan (2003) argue that, "an increase in GDP per capita would induce lower costs of rolling over shortterm debt and contribute to increased expectations of positive productivity shocks" which would "tend to raise the share of short-term debt."

A similar argument is made for the effect of Financial Development, measured as domestic credit to the private sector as percent of GDP. Rodrik \& Velasco (1999) and Buch \& Lusinyan (2003) find that greater financial development is indeed associated with a greater proportion of short-term debt. ${ }^{9}$

The data on international lending are also broken down in terms of borrowers - governments, financial institutions, and private non-financial institutions. This allows us to control for the composition of borrowers since government debt (which is 23.5 percent of total debt in our sample) generally tends to be longer-term, whereas claims on financial institutions (26.6 percent of total debt) generally tend to be shorter-term (Palmer, 2000). ${ }^{10}$ Government is the percent of total claims incurred by the government and Banks is the percent of total claims incurred by banking institutions. Government is expected to lengthen the maturity, while Banks is expected to shorten the maturity. Buch \& Lusinyan (2003) include a variable equivalent to Banks and find that lending to banks is associated with more short-term debt. Valev (2007) includes variables similar to Government and Banks and finds expected effects.

Total Claims present international debt of the entire economy. They are expected to shorten the maturity, as the countries that already accumulated high levels of debt tend to borrow more short-term (Missale \& Blanchard, 1994).

\section{RESULTS}

Table 2 presents results from the fixed-effects estimation. Investment profile significantly lengthens the maturity in all specifications. Similar results hold for Law and order, except in full model specification for the short-term debt. In terms of economic volatility, Exchange rate volatility does not influence the maturity. Inflation only marginally increases the share of short-term debt, while the Reserves volatility significantly reduces debt maturity in all specifications.

\footnotetext{
${ }^{9}$ Data on domestic credit to the private sector as a share of GDP are from Beck et al., 2000.

${ }^{10}$ Data do not provide the maturity composition of loans to each of these borrowers, but provide a distribution of the overall loan amounts in terms of borrower type.
}

Vol. 23, број 1/2021, cmp. 17-34 
Imports and Financial development do not influence maturity distribution. This may be surprising as we expected that great portion of the short-term credit is used for financing trade. Higher GDP per capita is associated with longer debt maturity. The finding that GDP per capita has a negative effect on short-term foreign debt (i.e., poorer countries tend to borrow more short-term) is novel. We find that the main driving force behind this result are the non-OECD countries and countries with French legal origin (see Tables 4). For example, the results suggest that if you are not an OECD member, the maturity increases with income. If you are the OECD member, you are, on average, getting longer maturity regardless of your income level.

The result on GDP indicates that the determination of foreign debt maturity does not come from the demand side. Instead, we confirm the supply side theory which states that the banks are limiting maturity of the debt they extend to the poorer countries because of the higher perceived risk of these debtors. This approach is theoretically supported by the Flannery's (1986) \& Diamond's (1991) model, which explain how banks manage riskier borrowers by shortening the maturity of the debt they extend to them.

As expected, the share of the debt incurred by banks significantly shortens the maturity, while the share of the debt incurred by governments significantly lengthens the maturity. Total claims significantly shorten the maturity of debt in most specifications. Similary Missale \& Blanchard (1994) show, in sample of OECD countries, that the there is an inverse relationship between the level of debt and its maturity after a certain level of debt has been reached (i.e. countries that already accumulated high levels of debt tend to borrow more short-term).

Table 3 is included as a check and it considers cross section of countries. Law and order remains significant determinant of maturity, while the Investment profile does not influence maturity in the cross section. Economic uncertainty, Imports, Financial development, and Percent claims on government do not influence maturity. Percent claims on banks significantly lowers the maturity. From Table 3 we also see that GDP per capita and Total claims have the opposite sign compared to the panel estimation, but similar sign compared to the previous cross-section research. Inability to capture country-specific unobservable in the crosssection setting may be the cause of this difference between panel and crosssection results.

Table 4 presents results for the estimations of subsamples divided by the legal origin. We see that Law and order is not important determinant in any subsample, while Investment profile matters mostly for foreign debt maturity in countries with French and British legal origin. Exchange rate 
Fear of commitment: weak institutions, volatile economy, and the prevalence of..

volatility lengthens the foreign debt maturity in countries with Socialist and German legal origin, while it shortens the maturity in Scandinavian countries. Reserves volatility shortens the foreign debt maturity in countries with German, French, and Socialist legal origin, while Inflation shortens the foreign debt maturity in countries with British and French legal origin. Imports tend to lengthen the maturity in countries with German legal origin, while they tend to shorten the maturity in countries with Socialist legal origin. GDP per capita lengthens the maturity only in countries with French legal origin. Greater domestic bank lending lengthens the maturity in countries with Scandinavian legal origin, while foreign bank lending is not significant in any subsample. Share of bank incurred debt shortens maturity in countries with German and Socialist legal origin, while the share of government incurred debt lengthens the maturity in countries with British and French legal origin.

Table 5 presents estimations for subsamples organized according to OECD membership and income groups. Results suggest that the result of Law and order is driven primarily by the high income group. Investment profile, on the other hand, lengthens the maturity for OECD member and non-member countries and the impact on member countries is larger than on non-member countries. Furthermore, Investment profile is important for richer countries, as magnitude and statistical significance of its coefficient increase with income. Economic uncertainty has different impact on different groups of countries, depending on measure we use. Exchange rate volatility shortens the maturity of foreign debt only in high income countries. Reserves volatility shortens the maturity of foreign debt in OECD countries and in upper middle income and low income countries. Inflation, on the other hand, tends to shorten the maturity in non-OECD countries and countries with lower income. In high income group Inflation leads to lower share of short-term debt.

Imports shorten the maturity in the upper middle income countries. Previous literature confirms similar findings in the upper middle income countries, but we also find that imports lengthen the maturity in low income countries. GDP per capita lengthens the maturity of foreign debt in nonOECD countries and in low and upper middle income groups. Financial development lengthens the maturity in OECD countries, while it substantially shortens the maturity in low income countries. Greater share of cross-border debt incurred by banks shortens the maturity across OECD membership and in high and lower middle income groups, while the greater share of government incurred debt lengthens the maturity everywhere except in high income and OECD countries. The results on bank share of debt are expected. Results on government share of debt can be explained as follows: in rich economies governments tend to borrow less, perhaps 
only when short on cash (hence, the positive coefficient in estimating shortterm debt); rich governments do not need to borrow long-term to finance infrastructure projects, etc. Total claims shorten the maturity of foreign debt only in non-OECD countries.

Table 6 presents estimations for the three subsamples divided by time periods. From the estimations we see that institutional uncertainty does not play important role in any subsample. Therefore, although institutions have crucial importance for the maturity of foreign debt, their impact is not observable over the short time horizon. Economic uncertainty remains the significant determinant of the maturity of foreign debt. Exchange rate volatility shortens the foreign debt maturity from 1983 to 1992, Reserves volatility shortens the maturity from 1983 to 1992 and from 2003 to 2012, while Inflation does not have a significant impact. Imports and Total claims do not influence maturity over the short horizon, while GDP per capita significantly lengthens the maturity in the first two subsamples. The share of bank incurred foreign debt shortens the maturity from 1983 to 1992 and from 2003 to 2012, while the share of government incurred foreign debt lengthens the maturity from 1993 to 2002. Financial development is marginally important only in the last subsample.

Table 7 presents results of Hausman-Taylor instrumental variable estimations where Claims on banks, Claims on government, and Total claims are endogenous. We see that both measures of institutions significantly lengthen the maturity of foreign debt in all specifications. Reserves volatility significantly shortens the maturity of foreign debt in all specifications, impact of Inflation is significant only for the share of shortterm debt, while Exchange rate volatility does not influence maturity. Imports and Financial development are not important determinants of maturity, while GDP per capita significantly lengthens the maturity in all specifications. Claims on banks significantly shorten the maturity, while Claims on governments significantly lengthen the maturity in all specifications. Total claims shorten the maturity of foreign debt, but the impact is only marginally significant. Hausman-Taylor estimations also allow for estimation of the impact of legal origin. From the results we see that Socialist legal origin significantly lengthens the maturity of foreign debt in all specifications.

\section{CONCLUSION}

This paper investigates determinants of the cross-border bank credit maturity using a large panel data set on international bank lending to 135 countries from 1983 to 2012. This paper presents first analysis of international credit maturity that covers wide range of countries in a panel 
Fear of commitment: weak institutions, volatile economy, and the prevalence of..

data setting and covers lending activities of all BIS reporting banks. The particular emphasis of this paper is the role of legal and political institutions and economic volatility. We find that weak rule of law and political uncertainty significantly reduce the fraction of international credit that is long-term. Furthermore, we find that the effect of weak rule of law is particularly pronounced in more developed economies. While economic volatility generally tends to shorten the maturity of international credit, higher inflation lengthens the maturity in high income countries and the exchange rate volatility lengthens the maturity in countries with Socialist and German legal origin.

We find that over the short horizon, economic volatility is more important determinant of maturity compared to legal and political institutions. However, over the long horizon effects of economic volatility disappear while the role of institutions becomes more important. This is important from the policy perspective, as governments should work on achieving political, legal, and institutional stability in the long run, but also, with the help of central banks, should provide economic stability even in the short run.

We also report new and opposing findings compared to crosssectional research, research on lending from one country only, or research that considers only certain groups of countries. In particular, we find that higher per capita GDP is associated with longer debt maturity. The finding that GDP per capita has a negative effect on the share of short-term foreign debt is not confirmed in the previous literature mainly due to the lack of adequate data. We confirm the supply side theory which states that the banks are limiting maturity of the debt they extend to the poorer countries because of the higher perceived risk of these debtors.

\section{REFERENCES}

1. Aizenman, J. - Marion, N. (2002): Reserve Uncertainty and the Supply of International Credit. Journal of Money, Credit and Banking 34, 631-49.

2. Beck, T. - Demirgüç-Kunt, A. - Levine, R. (2000): A New Database on Financial Development and Structure. World Bank Economic Review 14, 597-605.

3. Buch, C. - Lusinyan, L. (2003): Determinants of Short-Term Debt: A Note. Journal of International Financial Markets, Institutions, and Money 13, 157-170.

4. Catao, L. - Sutton, B. (2002): Sovereign Defaults: The Role of Volatility. International Monetary Fund, Working Paper 02/149.

Vol. 23, број 1/2021, cmp. 17-34 
5. Chang, R. - Velasco, A. (2001): A Model Of Financial Crises In Emerging Markets, Quarterly Journal Of Economics 116, 489-517.

6. Citron, J. - Nickelsburg. G. (1987): Country Risk and Political Instability. Journal of Development Economics 25, 385-92.

7. De Haan, J. - Siermann, C. - Van Lubek, E. (1997): Political Instability and Country Risk: New Evidence. Applied Economics Letters 4, 703-707.

8. Demirgüç-Kunt, A. - Maksimovic, V. (1999): Institutions, Financial Markets, and Firm Debt Maturity. Journal of Financial Economics 54, 295-336.

9. Diamond, D. W. (1991): Debt Maturity Structure and Liquidity Risk. The Quarterly Journal of Economics 106, 709-737.

10. Diamond, D. W. (2004): Presidential Address, Committing to Commit: Short-Term Debt When Enforcement is Costly. Journal of Finance 59, 1447-1479.

11. Flannery, M. J. (1986): Asymmetric Information and Risky Debt Maturity Choice. Journal of Finance 41, 19-37.

12. Giannetti, M. (2003): Do Better Institutions Mitigate Agency Problems? Evidence from Corporate Finance Choices. Journal of Financial and Quantitative Analysis 38, 185-212.

13. Hausman, J. A. - Taylor, W. E. (1981): Panel Data and Unobservable Individual Effects. Econometrica 49, 1377-1398.

14. Missale, A. - Blanchard, O. J. (1994): The Debt Burden and Debt Maturity. American Economic Review, vol. 84, issue 1, 309-19

15. Ozler, S. - Tabellini, G. (1991): External Debt and Political Instability. National Bureau of Economic Research, Working Paper 3772.

16. Palmer, D. (2000): U.S. Bank Exposure to Emerging-Market Countries during Recent Financial Crises. Federal Reserve Bulletin, February, 983-1014.

17. Papke, L. E. - Wooldridge, J. M. (1996): Econometric Methods for Fractional Response Variables with an Application to 401(K) Plan Participation Rates. Journal of Applied Econometrics 11, 619-632.

18. Qian, J. - Strahan, P. E. (2007): How Laws and Institutions Shape Financial Contracts: The Case of Bank Loans. Journal of Finance 62, 2803-2834.

19. Radelet, S. - Sachs, J. (1998): The Onset of the East Asian Financial Crisis. National Bureau of Economic Research. Working Paper no. 6680.

20. Rajan, R. G. (1992): Insiders and Outsiders: The Choice Between Informed and Arm's-Length Debt. Journal of Finance 47, 13671400 . 
Fear of commitment: weak institutions, volatile economy, and the prevalence of..

21. Rodrik, D. - Velasco, A. (1999): Short-Term Capital Flows. Annual World Bank Conference on Development Economics 1999: The World Bank: Washington, D.C.

22. Tasić, N. - Valev, N. T. (2010): The Provision of Long-Term Financing in the Transition Economies. Journal of Comparative Economics 38, 160-172.

23. Valev, N. T. (2006): Institutional Uncertainty and the Maturity of International Loans. Journal of International Money and Finance 25, 780-794.

24. Valev, N. T. (2007): Uncertainty and International Debt Maturity. Journal of International Financial Markets, Institutions and Money 17, 372-386.

Рад је примљен: 30. деиембра 2020. Рад је прихваћен за штампу: 21. јануара 2021. 
Никола Тасић, Владимир Ристановић

ANEX (Author's calculations)

Table 1.: The Level and Maturity of Foreign Debt by Income, OECD Membership, and Legal Origin

\begin{tabular}{lccr}
\hline & Total Claims & Percent Short-Term & Percent Long-Term \\
\hline & World Bank Income Groups & & \\
\hline High Income & 233.24 & 56.08 & 39.05 \\
\hline Upper Middle Income & 21.21 & 44.28 & 48.88 \\
\hline Lower Middle Income & 10.76 & 49.50 & 43.60 \\
\hline Low Income & 2.89 & 51.81 & 41.30 \\
\hline \multicolumn{4}{c}{ OECD Membership } \\
\hline Member Countries & 395.47 & 49.74 & 45.49 \\
\hline Non-Member Countries & 13.42 & 50.77 & 42.58 \\
\hline & Legal Origin & & 38.92 \\
\hline British & 80.98 & 55.48 & 43.33 \\
\hline French & 42.72 & 49.89 & 36.82 \\
\hline German & 419.91 & 58.89 & 51.60 \\
\hline Socialist & 20.24 & 40.76 & 47.62 \\
\hline Scandinavian & 72.61 & 47.58 &
\end{tabular}

Table 2.: Determinants of Maturity of Foreign Debt

\begin{tabular}{|c|c|c|c|c|c|c|c|c|}
\hline \multicolumn{9}{|c|}{ Percent of Total Claims with Maturity of One Year or Less (1-7) and Longer than Two Years (8) } \\
\hline & (1) & (2) & (3) & (4) & (5) & (6) & (7) & (8) \\
\hline \multirow{2}{*}{$\begin{array}{l}\text { Law and } \\
\text { order }\end{array}$} & $-1.350 * *$ & $-1.358 * *$ & $-1.286^{* *} *$ & & & & -0.861 & $1.038^{*}$ \\
\hline & {$[0.649]$} & {$[0.627]$} & [0.647] & & & & [0.592] & {$[0.540]$} \\
\hline \multirow{3}{*}{$\begin{array}{l}\text { Investment } \\
\text { profile }\end{array}$} & & & & - & - & - & - & $1.074 * * *$ \\
\hline & & & & $0.871 * * *$ & $0.893 * * *$ & $0.820 * * *$ & $0.788^{* * * *}$ & \\
\hline & & & & {$[0.263]$} & {$[0.252]$} & {$[0.254]$} & {$[0.257]$} & {$[0.246]$} \\
\hline \multirow{2}{*}{$\begin{array}{l}\text { Exchange } \\
\text { rate } \\
\text { volatility }\end{array}$} & 0.032 & & & 0.028 & & & -0.028 & 0.025 \\
\hline & {$[0.019]$} & & & {$[0.022]$} & & & {$[0.032]$} & {$[0.032]$} \\
\hline \multirow[t]{2}{*}{$\begin{array}{l}\text { Reserves } \\
\text { volatility }\end{array}$} & & $0.035 * * *$ & & & $0.037 * * *$ & & $0.036 * * *$ & $-\overline{0.035 * * *}$ \\
\hline & & {$[0.007]$} & & & {$[0.008]$} & & {$[0.008]$} & {$[0.009]$} \\
\hline \multirow[t]{2}{*}{ Inflation } & & & $0.069^{*}$ & & & 0.054 & $0.084^{*}$ & -0.051 \\
\hline & & & {$[0.035]$} & & & {$[0.037]$} & {$[0.043]$} & [0.044] \\
\hline \multirow{2}{*}{$\begin{array}{l}\text { Imports / } \\
\text { GDP }\end{array}$} & -0.082 & -0.073 & -0.079 & -0.057 & -0.047 & -0.055 & -0.066 & 0.085 \\
\hline & {$[0.063]$} & {$[0.063]$} & {$[0.064]$} & {$[0.060]$} & {$[0.060]$} & {$[0.061]$} & {$[0.061]$} & {$[0.055]$} \\
\hline \multirow[t]{3}{*}{ GDP p.c. } & - & - & - & - & - & - & - & 0.278 *** \\
\hline & $0.369 * * *$ & $0.354 * * *$ & $0.355^{* * * * *}$ & 0.281 *** & $0.276 * * *$ & $0.282 * * *$ & $0.300^{* * * *}$ & \\
\hline & {$[0.084]$} & {$[0.081]$} & {$[0.080]$} & {$[0.088]$} & {$[0.081]$} & {$[0.080]$} & {$[0.085]$} & {$[0.080]$} \\
\hline \multirow{2}{*}{$\begin{array}{c}\text { Financial } \\
\text { develop. }\end{array}$} & -1.491 & -2.220 & -1.685 & -0.971 & -1.998 & -1.623 & -0.575 & -0.085 \\
\hline & {$[2.845]$} & {$[2.664]$} & {$[2.625]$} & [2.739] & {$[2.552]$} & {$[2.514]$} & {$[2.767]$} & {$[2.706]$} \\
\hline \multirow{2}{*}{$\begin{array}{l}\text { Claims on } \\
\text { banks (\%) }\end{array}$} & $0.186^{* * *}$ & $0.186 * * *$ & $0.182^{* * * *}$ & $0.165^{* * *} *$ & $0.166^{* * *} *$ & $0.163^{* * *}$ & 0.160 ***⿰㇇⿰亅⿱丿丶丶 & $-0.132 * *$ \\
\hline & {$[0.060]$} & {$[0.058]$} & {$[0.058]$} & {$[0.061]$} & [0.059] & {$[0.060]$} & {$[0.061]$} & {$[0.054]$} \\
\hline \multirow{3}{*}{$\begin{array}{l}\text { Claims on } \\
\text { gov. }(\%)\end{array}$} & - & - & - & - & - & - & - & $0.162 * * *$ \\
\hline & $0.141^{* * *} *$ & $0.134 * * *$ & $0.153^{* * * *}$ & $0.156^{* * * *}$ & $0.151 * * *$ & $0.168 * * *$ & $0.174 * * *$ & \\
\hline & {$[0.032]$} & {$[0.032]$} & {$[0.032]$} & {$[0.035]$} & {$[0.034]$} & {$[0.035]$} & {$[0.035]$} & {$[0.034]$} \\
\hline \multirow[t]{2}{*}{ Total claims } & $0.007^{*}$ & $0.005^{*}$ & 0.007 ** & $0.006^{*}$ & $0.005^{*}$ & $0.006^{* *}$ & 0.004 & -0.004 \\
\hline & {$[0.003]$} & {$[0.003]$} & {$[0.003]$} & {$[0.003]$} & {$[0.002]$} & {$[0.003]$} & {$[0.003]$} & {$[0.003]$} \\
\hline \multirow[t]{2}{*}{ Constant } & $\begin{array}{l}60.170 * * \\
*\end{array}$ & $\begin{array}{l}59.800 * * \\
*\end{array}$ & $\begin{array}{l}60.056^{* *} \\
*\end{array}$ & $\begin{array}{l}60.946 * * \\
*\end{array}$ & $\begin{array}{l}60.873 * * \\
*\end{array}$ & $\begin{array}{l}60.896 * * \\
*\end{array}$ & $\begin{array}{l}64.065^{* *} \\
*\end{array}$ & $\begin{array}{l}25.889 * * \\
*\end{array}$ \\
\hline & {$[4.660]$} & [4.595] & {$[4.730]$} & [4.666] & [4.627] & {$[4.713]$} & {$[5.260]$} & [4.796] \\
\hline $\begin{array}{l}\text { Observation } \\
\mathrm{s}\end{array}$ & 2,847 & 2,914 & 2,906 & 2,847 & 2,914 & 2,906 & 2,796 & 2,796 \\
\hline Countries & 135 & 135 & 135 & 135 & 135 & 135 & 135 & 135 \\
\hline$R^{2}$ & 0.102 & 0.108 & 0.109 & 0.107 & 0.115 & 0.114 & 0.121 & 0.120 \\
\hline
\end{tabular}


Fear of commitment: weak institutions, volatile economy, and the prevalence of..

Table 3.: Determinants of Maturity of Foreign Debt in a Cross Section of Countries

\begin{tabular}{lllll}
\hline & \multicolumn{2}{c}{ Percent Short-Term } & \multicolumn{2}{c}{ Percent Long-Term } \\
\hline Law and order & $-4.312^{* * *}$ & {$[1.347]$} & $3.935^{* * *}$ & {$[1.265]$} \\
\hline Investment profile & -0.933 & {$[0.894]$} & 0.904 & {$[0.839]$} \\
\hline Exchange rate volatility & 0.041 & {$[0.453]$} & -0.102 & {$[0.425]$} \\
\hline Reserves volatility & 0.028 & {$[0.050]$} & -0.018 & {$[0.047]$} \\
\hline Inflation & -0.167 & {$[0.453]$} & 0.274 & {$[0.425]$} \\
\hline Imports as a share of GDP & 0.000 & {$[0.046]$} & 0.008 & {$[0.043]$} \\
\hline GDP per capita & $0.351^{* *}$ & {$[0.141]$} & $-0.274^{* *}$ & {$[0.132]$} \\
\hline Financial development & 4.762 & {$[4.783]$} & -4.220 & {$[4.491]$} \\
\hline Percent claims on banks & $0.464^{* * *}$ & {$[0.089]$} & $-0.411^{* * *}$ & {$[0.083]$} \\
\hline $\begin{array}{l}\text { Percent claims on } \\
\text { government }\end{array}$ & -0.132 & {$[0.106]$} & 0.151 & {$[0.099]$} \\
\hline Total claims & $-2.170^{* * *}$ & {$[0.631]$} & $2.075^{* * *}$ & {$[0.592]$} \\
\hline Constant & $61.352^{* * *}$ & {$[7.723]$} & $30.702^{* * *}$ & {$[7.251]$} \\
\hline Observations & 135 & & 135 & \\
\hline$R^{2}$ & 0.352 & & 0.331 & \\
\hline Notes: & $* * *$ & & \\
\hline
\end{tabular}

Notes: $\quad * *, * * *$ indicate significance at the 5 and 1 percent confidence level, respectively. Standard errors are reported in parentheses below coefficients.

Table 4.: Determinants of Short-Term Debt by Legal Origin

\begin{tabular}{|c|c|c|c|c|c|}
\hline & \multicolumn{5}{|c|}{ Legal Origin } \\
\hline & British & French & German & Socialist & Scandinavian \\
\hline \multirow[t]{2}{*}{ Law and order } & -0.239 & -0.597 & 0.952 & 0.520 & 0.000 \\
\hline & {$[0.742]$} & {$[0.873]$} & {$[1.103]$} & {$[2.223]$} & {$[0.000]$} \\
\hline \multirow[t]{2}{*}{ Investment profile } & $-0.865^{*}$ & $-0.786^{* *}$ & -0.056 & -0.181 & -1.003 \\
\hline & {$[0.456]$} & {$[0.371]$} & [0.709] & {$[0.582]$} & {$[0.626]$} \\
\hline \multirow{2}{*}{$\begin{array}{l}\text { Exchange rate } \\
\text { volatility }\end{array}$} & -18.081 & -0.016 & $-682.635^{*}$ & $-44.479 * * *$ & $523.879 *$ \\
\hline & [13.805] & {$[0.031]$} & [282.838] & [11.270] & [201.917] \\
\hline \multirow[t]{2}{*}{ Reserves volatility } & -0.017 & $0.192 *$ & $0.124 * * *$ & $0.033^{*}$ & 1.421 \\
\hline & {$[0.060]$} & {$[0.096]$} & {$[0.009]$} & {$[0.019]$} & [1.054] \\
\hline \multirow[t]{2}{*}{ Inflation } & $4.123 * *$ & $0.074 *$ & -6.928 & 0.243 & -0.980 \\
\hline & [1.639] & {$[0.038]$} & [8.402] & {$[0.149]$} & {$[2.031]$} \\
\hline Imports as a share & -0.069 & -0.170 & $-0.420 * * *$ & $0.187 *$ & -0.074 \\
\hline of GDP & {$[0.064]$} & {$[0.137]$} & {$[0.071]$} & {$[0.097]$} & {$[0.800]$} \\
\hline \multirow[t]{2}{*}{ GDP per capita } & -0.211 & $-0.496 * * *$ & -0.157 & -0.294 & 0.462 \\
\hline & {$[0.234]$} & {$[0.085]$} & {$[0.090]$} & {$[0.367]$} & {$[0.230]$} \\
\hline Financial & -1.255 & -0.301 & -9.700 & -0.265 & $-8.387 * *$ \\
\hline development & [4.617] & {$[6.875]$} & [6.439] & {$[4.762]$} & [2.675] \\
\hline \multirow{2}{*}{$\begin{array}{l}\text { Percent claims on } \\
\text { banks }\end{array}$} & 0.109 & 0.152 & $0.496 * *$ & $0.300 * *$ & 0.289 \\
\hline & {$[0.080]$} & {$[0.106]$} & {$[0.122]$} & {$[0.115]$} & {$[0.283]$} \\
\hline \multirow{2}{*}{$\begin{array}{l}\text { Percent claims on } \\
\text { government }\end{array}$} & $-0.157 * * *$ & $-0.223^{* * *}$ & 0.186 & -0.143 & -0.206 \\
\hline & {$[0.043]$} & {$[0.051]$} & {$[0.123]$} & {$[0.122]$} & {$[0.099]$} \\
\hline \multirow[t]{2}{*}{ Total claims } & 0.002 & 0.010 & 0.003 & -0.009 & -0.030 \\
\hline & {$[0.003]$} & {$[0.006]$} & {$[0.003]$} & {$[0.047]$} & {$[0.052]$} \\
\hline \multirow[t]{2}{*}{ Constant } & $66.594 * * *$ & $67.218 * * *$ & $49.452 * *$ & $24.754 *$ & $38.371^{*}$ \\
\hline & {$[6.606]$} & {$[8.262]$} & [14.000] & [13.177] & [13.878] \\
\hline Observations & 933 & 1,373 & 71 & 354 & 65 \\
\hline Countries & 40 & 61 & 5 & 24 & 5 \\
\hline$R^{2}$ & 0.153 & 0.136 & 0.674 & 0.311 & 0.401 \\
\hline
\end{tabular}

Notes: $\quad *, * *, * * *$ indicate significance at the 10,5 , and 1 percent confidence level, respectively. Robust standard errors are reported in parentheses below coefficients. 
Никола Тасић, Владимир Ристановић

Table 5.: Determinants of Short-Term Debt by OECD Membership and Income

\begin{tabular}{|c|c|c|c|c|c|c|}
\hline & \multicolumn{2}{|c|}{$O E C D$} & \multicolumn{4}{|c|}{ World Bank Income Groups } \\
\hline & & & & Upper & Lower & \\
\hline & & Non- & High & Middle & Middle & Low \\
\hline & Member & Member & Income & Income & Income & Income \\
\hline \multirow[t]{2}{*}{ Law and order } & 0.436 & -0.974 & $-3.127 * *$ & 0.635 & 0.536 & -1.006 \\
\hline & {$[0.736]$} & [0.609] & [1.303] & [1.199] & [0.916] & [1.071] \\
\hline \multirow{2}{*}{$\begin{array}{l}\text { Investment } \\
\text { profile }\end{array}$} & $-0.946^{* *}$ & $-0.721 * *$ & $-1.660 * * *$ & -0.580 & -0.296 & -0.352 \\
\hline & {$[0.388]$} & [0.289] & {$[0.303]$} & {$[0.417]$} & {$[0.386]$} & {$[0.590]$} \\
\hline \multirow{2}{*}{$\begin{array}{l}\text { Exchange rate } \\
\text { volatility }\end{array}$} & 231.912 & -0.024 & $22.845^{* *}$ & 0.121 & -0.008 & -0.813 \\
\hline & {$[176.479]$} & {$[0.033]$} & [9.219] & {$[0.165]$} & {$[0.014]$} & {$[0.504]$} \\
\hline \multirow{2}{*}{$\begin{array}{l}\text { Reserves } \\
\text { volatility }\end{array}$} & $0.092 * *$ & 0.011 & 0.041 & $0.103 * * *$ & 0.036 & $0.798 *$ \\
\hline & [0.039] & {$[0.012]$} & {$[0.057]$} & {$[0.031]$} & {$[0.027]$} & {$[0.437]$} \\
\hline \multirow[t]{2}{*}{ Inflation } & -1.939 & $0.085^{*}$ & $-2.511 * *$ & -0.257 & $0.095 * * *$ & 1.818 \\
\hline & {$[2.738]$} & {$[0.044]$} & {$[0.936]$} & {$[0.154]$} & {$[0.031]$} & [1.356] \\
\hline \multirow{2}{*}{$\begin{array}{l}\text { Imports as a } \\
\text { share of GDP }\end{array}$} & -0.030 & -0.081 & -0.080 & $0.232 * * *$ & -0.071 & $-0.320 * *$ \\
\hline & {$[0.179]$} & {$[0.062]$} & {$[0.064]$} & {$[0.066]$} & [0.116] & {$[0.125]$} \\
\hline \multirow{2}{*}{$\begin{array}{l}\text { GDP per } \\
\text { capita }\end{array}$} & 0.056 & $-0.534 * * *$ & -0.027 & $-0.576^{*}$ & -1.012 & $-15.862^{*}$ \\
\hline & {$[0.116]$} & {$[0.124]$} & {$[0.075]$} & {$[0.314]$} & [0.859] & [7.852] \\
\hline \multirow{2}{*}{$\begin{array}{l}\text { Financial } \\
\text { development }\end{array}$} & $-6.567 *$ & -1.936 & -1.482 & -10.413 & 1.019 & $42.517 * * *$ \\
\hline & [3.440] & [3.652] & [3.330] & {$[6.232]$} & [6.478] & {$[14.431]$} \\
\hline \multirow{2}{*}{$\begin{array}{l}\text { Percent claims } \\
\text { on banks }\end{array}$} & $0.383^{* * *}$ & $0.140^{* *}$ & $0.358 * * *$ & 0.180 & $0.169 *$ & 0.071 \\
\hline & {$[0.108]$} & {$[0.066]$} & {$[0.070]$} & {$[0.126]$} & {$[0.094]$} & {$[0.110]$} \\
\hline \multirow{2}{*}{$\begin{array}{l}\text { Percent claims } \\
\text { on } \\
\text { government }\end{array}$} & -0.076 & $-0.180^{* * *}$ & 0.038 & $-0.181 * * *$ & $-0.169 * * *$ & $-0.224 * * *$ \\
\hline & [0.079] & {$[0.037]$} & {$[0.077]$} & [0.059] & {$[0.058]$} & {$[0.061]$} \\
\hline \multirow[t]{2}{*}{ Total claims } & -0.001 & $0.054 * *$ & -0.000 & 0.012 & 0.003 & -0.230 \\
\hline & {$[0.002]$} & {$[0.027]$} & {$[0.002]$} & {$[0.036]$} & {$[0.067]$} & {$[0.197]$} \\
\hline \multirow[t]{2}{*}{ Constant } & $47.035 * * *$ & $65.548 * * *$ & $78.418^{* * * *}$ & $44.654 * * *$ & $53.964 * * *$ & $70.244 * * *$ \\
\hline & [6.618] & {$[5.533]$} & [11.010] & [8.468] & [7.994] & [8.914] \\
\hline Observations & 335 & 2,461 & 631 & 551 & 846 & 768 \\
\hline Countries & 24 & 111 & 37 & 26 & 39 & 33 \\
\hline$R^{2}$ & 0.392 & 0.121 & 0.379 & 0.220 & 0.150 & 0.140 \\
\hline
\end{tabular}

Notes: $* * *, * * *$ indicate significance at the 10,5 , and 1 percent confidence level, respectively. Robust standard errors are reported in parentheses below coefficients. 
Fear of commitment: weak institutions, volatile economy, and the prevalence of..

Table 6.: Determinants of Short-Term Debt over Time

\begin{tabular}{|c|c|c|c|}
\hline & & Time period & \\
\hline & $1983-1992$ & $1993-2002$ & $2003-2012$ \\
\hline \multirow[t]{2}{*}{ Law and order } & -1.178 & 0.917 & -1.321 \\
\hline & [1.145] & {$[0.766]$} & [1.808] \\
\hline \multirow[t]{2}{*}{ Investment profile } & 0.311 & -0.201 & -0.811 \\
\hline & {$[0.542]$} & {$[0.251]$} & {$[0.646]$} \\
\hline \multirow[t]{2}{*}{ Exchange rate volatility } & $0.092 * * *$ & -0.033 & -4.765 \\
\hline & {$[0.031]$} & {$[0.027]$} & [7.363] \\
\hline \multirow[t]{2}{*}{ Reserves volatility } & $4.025 * * *$ & -0.139 & $0.019 * * *$ \\
\hline & [1.092] & {$[0.096]$} & {$[0.006]$} \\
\hline \multirow[t]{2}{*}{ Inflation } & -0.016 & 0.046 & -0.486 \\
\hline & {$[0.031]$} & {$[0.038]$} & {$[0.899]$} \\
\hline \multirow[t]{2}{*}{ Imports as a share of GDP } & -0.061 & -0.010 & 0.079 \\
\hline & {$[0.095]$} & {$[0.090]$} & [0.049] \\
\hline \multirow[t]{2}{*}{ GDP per capita } & $-0.718 *$ & $-0.789 * * *$ & -0.051 \\
\hline & [0.374] & {$[0.301]$} & {$[0.108]$} \\
\hline \multirow[t]{2}{*}{ Financial development } & 7.109 & -5.929 & $-5.625^{*}$ \\
\hline & [8.729] & [4.321] & {$[2.934]$} \\
\hline \multirow{2}{*}{ Percent claims on banks } & $0.141 * *$ & 0.128 & $0.238 * * *$ \\
\hline & {$[0.067]$} & {$[0.103]$} & {$[0.071]$} \\
\hline \multirow{2}{*}{$\begin{array}{l}\text { Percent claims on } \\
\text { government }\end{array}$} & -0.049 & $-0.216^{* * *}$ & -0.052 \\
\hline & {$[0.034]$} & {$[0.068]$} & {$[0.086]$} \\
\hline \multirow[t]{2}{*}{ Total claims } & -0.146 & 0.022 & 0.001 \\
\hline & {$[0.088]$} & {$[0.018]$} & {$[0.002]$} \\
\hline \multirow[t]{2}{*}{ Constant } & 51.769 *** & $59.314 * * *$ & $52.875 * * *$ \\
\hline & [5.971] & [6.424] & [8.477] \\
\hline Observations & 680 & 1,077 & 1,039 \\
\hline Countries & 88 & 133 & 134 \\
\hline$R^{2}$ & 0.105 & 0.093 & 0.072 \\
\hline
\end{tabular}

Notes: *,**,*** indicate significance at the 10,5 , and 1 percent confidence level, respectively. Robust standard errors are reported in parentheses below coefficients. 
Никола Тасић, Владимир Ристановић

Table 7.: Determinants of Maturity of Foreign Debt (Hausman-Taylor Estimation)

\begin{tabular}{|c|c|c|c|c|c|c|c|c|}
\hline \multicolumn{9}{|c|}{ Percent of Total Claims with Maturity of One Year or Less (1-7) and Longer than Two Years (8) } \\
\hline & $(1)$ & $(2)$ & $(3)$ & $(4)$ & $(5)$ & $(6)$ & $(7)$ & $(8)$ \\
\hline \multirow{2}{*}{$\begin{array}{l}\text { Law and } \\
\text { order }\end{array}$} & $-\overline{1.176^{* * *}}$ & $\begin{array}{l}- \\
1.243 * * *\end{array}$ & $\overline{1.124 * * *}$ & & & & $-0.754 * *$ & $0.915 * * *$ \\
\hline & {$[0.326]$} & {$[0.323]$} & {$[0.324]$} & & & & [0.334] & [0.321] \\
\hline \multirow[t]{2}{*}{$\begin{array}{l}\text { Investment } \\
\text { profile }\end{array}$} & & & & $\begin{array}{l}- \\
0.916^{* * * *}\end{array}$ & $\begin{array}{l}- \\
0.945^{* * * *}\end{array}$ & $\begin{array}{l}- \\
0.865 * * *\end{array}$ & $-\overline{0.853 * * *}$ & $1.131 * * *$ \\
\hline & & & & {$[0.151]$} & {$[0.144]$} & {$[0.146]$} & {$[0.152]$} & {$[0.147]$} \\
\hline \multirow{2}{*}{$\begin{array}{l}\text { Exchange } \\
\text { rate } \\
\text { volatility }\end{array}$} & 0.032 & & & 0.028 & & & -0.028 & 0.026 \\
\hline & {$[0.023]$} & & & {$[0.022]$} & & & {$[0.032]$} & {$[0.031]$} \\
\hline \multirow{2}{*}{$\begin{array}{l}\text { Reserves } \\
\text { volatility }\end{array}$} & & $0.034 * * *$ & & & $0.036^{* * *} *$ & & $0.034 * * *$ & $-0.033 * * *$ \\
\hline & & {$[0.009]$} & & & {$[0.009]$} & & {$[0.009]$} & {$[0.009]$} \\
\hline \multirow[t]{2}{*}{ Inflation } & & & $0.067 * *$ & & & 0.051 & $0.081 * *$ & -0.047 \\
\hline & & & {$[0.031]$} & & & {$[0.031]$} & {$[0.040]$} & {$[0.038]$} \\
\hline \multirow{2}{*}{$\begin{array}{l}\text { Imports / } \\
\text { GDP }\end{array}$} & -0.031 & -0.025 & -0.027 & -0.012 & -0.007 & -0.010 & -0.020 & 0.036 \\
\hline & {$[0.024]$} & {$[0.024]$} & {$[0.024]$} & {$[0.024]$} & {$[0.024]$} & {$[0.024]$} & {$[0.024]$} & {$[0.023]$} \\
\hline \multirow[t]{2}{*}{$\begin{array}{l}\text { GDP per } \\
\text { capita }\end{array}$} & $\begin{array}{l} \\
0.268 * * *\end{array}$ & $-\overline{0.266 * * *}$ & $-\overline{0.261 * * *}$ & $\begin{array}{l}- \\
0.183 * * *\end{array}$ & $-\overline{0.193 * * *}$ & $-\overline{0.193 * * *}$ & $-\overline{0.203 * * *}$ & $0.188 * * *$ \\
\hline & {$[0.059]$} & {$[0.055]$} & {$[0.055]$} & {$[0.060]$} & {$[0.056]$} & {$[0.056]$} & {$[0.060]$} & {$[0.058]$} \\
\hline \multirow{2}{*}{$\begin{array}{l}\text { Fin. deve- } \\
\text { lopment }\end{array}$} & -2.066 & $-2.896 *$ & -2.395 & -1.558 & $-2.632 *$ & -2.267 & -1.167 & 0.490 \\
\hline & [1.691] & {$[1.542]$} & [1.549] & [1.681] & {$[1.528]$} & {$[1.534]$} & [1.691] & {$[1.626]$} \\
\hline \multirow{2}{*}{$\begin{array}{l}\text { Claims on } \\
\text { banks }\end{array}$} & $0.203 * * *$ & $0.201 * * *$ & $0.197 * * *$ & $0.179 * * *$ & $0.177 * * *$ & $0.176 * * *$ & $0.173 * * *$ & $-0.145^{* * *}$ \\
\hline & {$[0.021]$} & {$[0.020]$} & {$[0.021]$} & {$[0.021]$} & {$[0.021]$} & {$[0.021]$} & {$[0.021]$} & {$[0.021]$} \\
\hline \multirow{3}{*}{$\begin{array}{l}\text { Claims on } \\
\text { government }\end{array}$} & - & - & - & - & - & - & - & $0.154 * * *$ \\
\hline & $0.128 * * *$ & $0.124 * * *$ & $0.141 * * *$ & $0.148 * * *$ & $0.145^{* * * *}$ & $0.160 * * *$ & $0.166 * * *$ & \\
\hline & {$[0.016]$} & {$[0.016]$} & {$[0.016]$} & {$[0.017]$} & {$[0.016]$} & {$[0.017]$} & [0.017] & {$[0.016]$} \\
\hline \multirow[t]{2}{*}{ Total claims } & $0.006^{*}$ & 0.005 & $0.006 * *$ & $0.005^{*}$ & 0.004 & $0.005^{*}$ & 0.004 & -0.004 \\
\hline & {$[0.003]$} & {$[0.003]$} & {$[0.003]$} & {$[0.003]$} & {$[0.003]$} & {$[0.003]$} & {$[0.003]$} & {$[0.003]$} \\
\hline \multirow{2}{*}{$\begin{array}{l}\text { British legal } \\
\text { origin }\end{array}$} & -3.384 & -5.873 & -1.365 & -3.619 & -4.402 & 0.090 & -4.695 & 3.732 \\
\hline & [7.627] & [7.185] & [6.943] & {$[7.325]$} & [6.936] & [6.718] & [7.465] & [7.178] \\
\hline \multirow{2}{*}{$\begin{array}{l}\text { French legal } \\
\text { origin }\end{array}$} & -10.246 & $-12.572 *$ & -8.192 & -9.832 & -10.618 & -6.269 & -11.351 & 9.517 \\
\hline & [7.666] & [7.155] & [6.898] & [7.357] & [6.899] & [6.666] & {$[7.498]$} & [7.210] \\
\hline \multirow{2}{*}{$\begin{array}{l}\text { German } \\
\text { legal origin }\end{array}$} & -3.353 & -3.037 & 1.744 & -6.114 & -1.426 & 3.434 & -0.765 & 0.675 \\
\hline & {$[9.385]$} & {$[8.750]$} & {$[8.473]$} & {$[9.102]$} & {$[8.450]$} & [8.192] & {$[9.034]$} & [8.687] \\
\hline \multirow{3}{*}{$\begin{array}{l}\text { Socialist } \\
\text { legal origin }\end{array}$} & - & - & - & - & - & - & - & $19.010 * *$ \\
\hline & $21.25 * * *$ & $24.59 * * *$ & $19.60 * * *$ & $21.09 * * *$ & $22.99 * * *$ & $17.96 * * *$ & $22.79 * * *$ & \\
\hline & {$[7.887]$} & [7.381] & [7.140] & {$[7.602]$} & [7.156] & [6.937] & {$[7.687]$} & [7.392] \\
\hline \multirow[t]{2}{*}{ Constant } & $65.43 * * *$ & $68.24 * * *$ & $63.47 * * *$ & $67.53 * * *$ & $68.91 * * *$ & $64.02 * * *$ & $71.84 * * *$ & $20.096 * * *$ \\
\hline & [7.930] & {$[7.427]$} & {$[7.192]$} & {$[7.582]$} & [7.071] & [6.860] & [7.876] & [7.574] \\
\hline Obs. & 2,847 & 2,914 & 2,906 & 2,847 & 2,914 & 2,906 & 2,796 & 2,796 \\
\hline Countries & 135 & 135 & 135 & 135 & 135 & 135 & 135 & 135 \\
\hline
\end{tabular}

